\title{
Article \\ Soybean (Glycine max (L.) Merr.) Growth, Yield, and Nodulation in the Early Transition Period from Conventional Tillage to Conservation and No-Tillage Systems
}

\author{
Sergeja Adamič * and Robert Leskovšek
}

Citation: Adamič, S.; Leskovšek, R. Soybean (Glycine max (L.) Merr.)

Growth, Yield, and Nodulation in the Early Transition Period from Conventional Tillage to Conservation and No-Tillage Systems. Agronomy 2021, 11, 2477. https://doi.org/ 10.3390/agronomy11122477

Academic Editor: Yash Dang

Received: 13 October 2021

Accepted: 2 December 2021

Published: 6 December 2021

Publisher's Note: MDPI stays neutral with regard to jurisdictional claims in published maps and institutional affiliations.

Copyright: (C) 2021 by the authors Licensee MDPI, Basel, Switzerland. This article is an open access article distributed under the terms and conditions of the Creative Commons Attribution (CC BY) license (https:/ / creativecommons.org/licenses/by/ $4.0 /)$.
Department of Agricultural Ecology and Natural Resources, Agricultural Institute of Slovenia, SI-1000 Ljubljana, Slovenia; robert.leskovsek@kis.si

* Correspondence: sergeja.adamic@kis.si; Tel.: +386-12805125

\begin{abstract}
Soybean (Glycine max (L.) Merr.) is the most important protein crop globally, with its cultivation area in Europe on the increase. To investigate how alternative tillage systems affect soybean growth, yield performance, and nitrogen fixation capacity in the early conversion period from conventional tillage to conservation and no-tillage practices, a field study was conducted in 2020 under the humid central European climatic conditions of Slovenia. A complete randomized block design with four repetitions was used for the three different tillage systems (conventional, conservation, and no-tillage). The results show that the majority of the studied soybean growth parameters (e.g., plant density, nodes per plant, and shoot and root dry matter) and the yield components (e.g., pods per plant, and 100-seed mass) were greatest for the reference conventional tillage system. The conventional system also showed significantly greater dry nodule mass $(p<0.01)$ and proportion of large-sized nodules $(>4 \mathrm{~mm})$ on both the tap root $(p<0.05)$ and the lateral roots $(p<0.001)$. A positive linear correlation between nitrogen content and nodule production in the roots also suggested increased nitrogen fixation for the conventional system. The less intensive conservation and no-tillage systems resulted in significantly greater soil compaction, which negatively affected early plant establishment and resulted in significantly decreased plant densities. Despite the large differences in plant stands and individual plant performances, no significant differences were seen for dry seed yields between these tillage systems. Dry seed yields for the conventional and conservation systems were 4.54 and $4.48 \mathrm{t} \mathrm{ha}^{-1}$, respectively, with only minor (non-significant) yield reduction for the no-tillage system, at $4.0 \mathrm{t} \mathrm{ha}^{-1}$. These data show that soybean cultivation in the early transition period to less intensive tillage systems have no major yield losses under these less suitable agro-climatic conditions if correct crop and weed management measures are implemented.
\end{abstract}

Keywords: soybean; tillage systems; early conversion stage; nitrogen fixation; yield components; soil compaction

\section{Introduction}

Soybean (Glycine max (L.) Merr.) is a legume crop and represents the largest source of plant protein worldwide. Due to global population growth and increased demand for soy-based animal feed, the worldwide soybean cultivation area is expanding. Genetically modified (GM) soybean represents almost $80 \%$ of the global production, although GM soybean in Europe is authorized only for food and animal feed. The leading soybean producers are the United States (32\%), followed by Brazil (28\%), Argentina (21\%), China $(7 \%)$, and India (4\%) [1,2]. The European domestic production of conventional soybean has also more than doubled in the last decade, although it represents only $7 \%$ of the total soybean demand in Europe [3,4].

Soybean is highly recommended for crop rotation due to its beneficial effects on soil fertility. Soybean has a high demand for nitrogen, and according to estimates by [5], $80 \mathrm{~kg}$ nitrogen is needed to produce $1000 \mathrm{~kg}$ soybean seeds. From $50 \%$ to $75 \%$ of the total 
nitrogen demand of soybean is provided by biological fixation, where atmospheric nitrogen is converted to ammonia [6]. This occurs through the symbiotic relationship with bacteria of the genus Bradyrhizobium, which enter the roots through infection of the root hairs, and form nodules [7]. As this biological nitrogen fixation is not always sufficient, nitrogen must also be added as a fertilizer to ensure optimal vegetative growth, which consequently provides higher seed yield [8,9]. In new soybean fields in particular, nitrogen addition is necessary due to the low bacterial population in the soil. Optimizing bacterial nitrogen fixation can therefore increase crop yields and reduce production costs [10].

Biological nitrogen fixation is also important because of the reduced need for nitrogen fertilization and its associated negative impact on the environment through nitrogen leaching [11]. The balance of nitrogen in the soil after a soybean harvest is usually more positive than with a non-legume crop. In addition to symbiotic fixation, part of the nitrogen is also released into the soil by decomposition of the soybean plant residues. Moreover, favorable carbon to nitrogen $(\mathrm{C} / \mathrm{N})$ ratios and fast mineralization of the plant residues provides reduced fertilizer requirements and beneficial effects on the yield of the succeeding crop [12].

The soil is a fundamental natural resource for agricultural production, and a recent report showed that most of the world soil resources are under considerable threat due to erosion, loss of soil carbon stock, and chemical pollution [13]. For the protection of natural resources, conservation and no-tillage systems have gained popularity in recent decades. With their production practices that include less intensive tillage, these systems offer lower production costs, increased water conservation, and minimized nutrient and soil losses through leaching and erosion [14]. As this tillage systems prevails in the leading soybean producing countries (i.e., USA, Argentina, Brazil), most of the soybean worldwide is grown under conservation and no-tillage systems. The increase in the area under conservation tillage was closely related to the adoption of GM soybean, as also for other GM crops [15]. Herbicide-tolerant crops make the use of conservation tillage practices easier, and large shifts from tillage-intensive systems to reduced or no-tillage systems occurred after implementation of herbicide-tolerant crops into the production system [16]. However, after being widely adopted in the past few decades, conservation tillage practices are threatened by increasing cases of herbicide-resistant weeds in affected areas throughout the world [17].

Conversion to alternative soil-tillage systems can have positive effects on the biological, physical, and chemical properties of the soil, which can then improve crop production. Along with management practices, the environmental, climate, and soil conditions are the key factors behind the soil organic content, and its structure and fertility [18]. However, large ranges in sequestration rates indicate that the magnitude of these changes is highly site specific and is also determined by the time since any management changes [19]. As a result, yield losses can often be observed in the early years of conversion to conservation and no-tillage systems [20].

In Europe, conservation agriculture and no-tillage systems are not as widely spread compared to other regions in the world, and the majority of soybean is grown in conventionally tilled soils [21]. There are also very contrasting data on soybean productivity for the different tillage systems in the literature. There are reports of soybean yield increase in the conventional tillage systems, while in other studies greater soybean yield was found in the no-tillage systems [22,23]. In contrast, several studies found no differences in the soybean yields in the conventional, conservation, and no-tillage systems [24,25].

As well as the effects of the tillage system on soybean productivity, significant differences can also be seen according to the soil microbial diversity and the dynamics that influence biological nitrogen fixation processes [26]. The quantity of fixed nitrogen can be measured with various methods; however, nodule traits can also be used as an indicator of nitrogen-fixing capacity $[27,28]$. It has been reported that both tillage system and tillage depth influence the number of nodules produced by soybean plants [29,30]. However, there are studies where the nodule production increased for no-tillage systems with di- 
rect seeding, as well as those where there was greater nodulation for conventional tillage systems [31,32].

Several studies have been carried out that have focused on the influence of tillage systems on growth and development of soybean, but few of these were conducted under less favorable humid-temperate climatic conditions of central Europe, where soybean cultivation is rapidly increasing. Furthermore, the aim of our study was to investigate how different tillage systems affect soybean yield performance in the early conversion period from conventional to conservation and no-tillage systems. The objective of our study was also to determine the nitrogen fixation capacities within the newly established alternative tillage systems, and their effects on soybean biomass production and seed yield.

\section{Materials and Methods}

\subsection{Study Site and Weather Conditions}

This study was carried out in 2020 in the experimental field of the Agricultural Institute of Slovenia (Infrastructure Centre Jablje pri Mengšu; $46^{\circ} 08^{\prime} 33.9^{\prime \prime} \mathrm{N}, 14^{\circ} 34^{\prime} 21.5^{\prime \prime} \mathrm{E}, 309 \mathrm{~m}$ a.s.l.). The experimental area was dominated by shallow to medium depth alluvial eutric brown soils on calcareous pebble and sand. The soils were well drained with silty-loam soil texture that comprised $25 \%$ clay, $37 \%$ silt, and $38 \%$ sand. Due to the high pebble content, these soils are prone to drought, as they have limited water storage capacity in the summer.

Soil samples were taken before the beginning of this study in March 2020 at a depth of 0 to $25 \mathrm{~cm}$. Soil analysis was performed at the Central Laboratory of the Agricultural Institute of Slovenia in Ljubljana, with the following characteristics measured: $\mathrm{pH}$ (in $\mathrm{KCl}$ ), available phosphorus and potassium $\left(\mathrm{P}_{2} \mathrm{O}_{5}, \mathrm{~K}_{2} \mathrm{O}\right.$, respectively; calcium-acetate-lactate method [33], organic carbon content [34] and total nitrogen [35]). The results of soil analysis showed that it was neutral ( $\mathrm{pH}$ 7.6) and well supplied with available phosphorus (30 $\mathrm{mg}$ $\left.\mathrm{kg}^{-1} \mathrm{P}_{2} \mathrm{O}_{5}\right)$ and potassium $\left(35 \mathrm{mg} \mathrm{kg}^{-1} \mathrm{~K}_{2} \mathrm{O}\right)$. The total nitrogen $(0.27 \%)$ and organic matter content $(4.3 \%)$ were high.

The precipitation and temperatures during the experimental season in 2020 were provided by a weather station near the experimental field (Adcon, A753GSM), and are compared with the 30-year long-term averages in Figure 1. These weather conditions were favorable for soybean growth and development. The mean temperature through the growing season from May to October was $16.9^{\circ} \mathrm{C}$, which was higher than the 30-year long-term average of $14^{\circ} \mathrm{C}$. The soybean plants were not exposed to water stress during their vegetative and generative development, because of the moderate temperatures and well-distributed precipitation during the summer months of 2020. The total precipitation from May to October was $868 \mathrm{~mm}$, which was also above the 30-year long-term average for the region (Figure 1).

\subsection{Experimental Design}

The experiment was arranged in a complete randomized block system, including three tillage systems: conventional, conservation, and no-tillage systems. The entire experimental field was $90 \mathrm{~m}$ in width and $80 \mathrm{~m}$ in length. Each tillage system was randomly assigned into four blocks (repetitions), each of which was $30 \mathrm{~m}$ in width and $20 \mathrm{~m}$ in length.

The experimental field was in the early tillage-conversion stage, with the different tillage methods established in autumn of 2018. The field experiment at the given site with soybean was conducted over only one year, due to crop rotation demands and the potential risk of pest and soil-borne pathogen damage related to second-year or continuous soybeans. The previous crop was winter wheat, which was drilled directly for the conservation and no-tillage systems, while the soil was prepared conventionally with ploughing and seedbed preparation for the conventional system. After the winter wheat harvest, the plant residues were left on the field and mulched, and the cover crop of berseem clover (Trifolium alexandrinum L.) was sown on 10 August 2019. For the conventional and conservation systems, the stubble was tilled with a disc harrow, while in the no-tillage system, the cover crop was sown directly into the winter wheat stubble. The cover crop establishment 
and development were extremely well, with over $5 \mathrm{tha}^{-1}$ of cover crop dry matter (DM) production for all of these tillage systems.

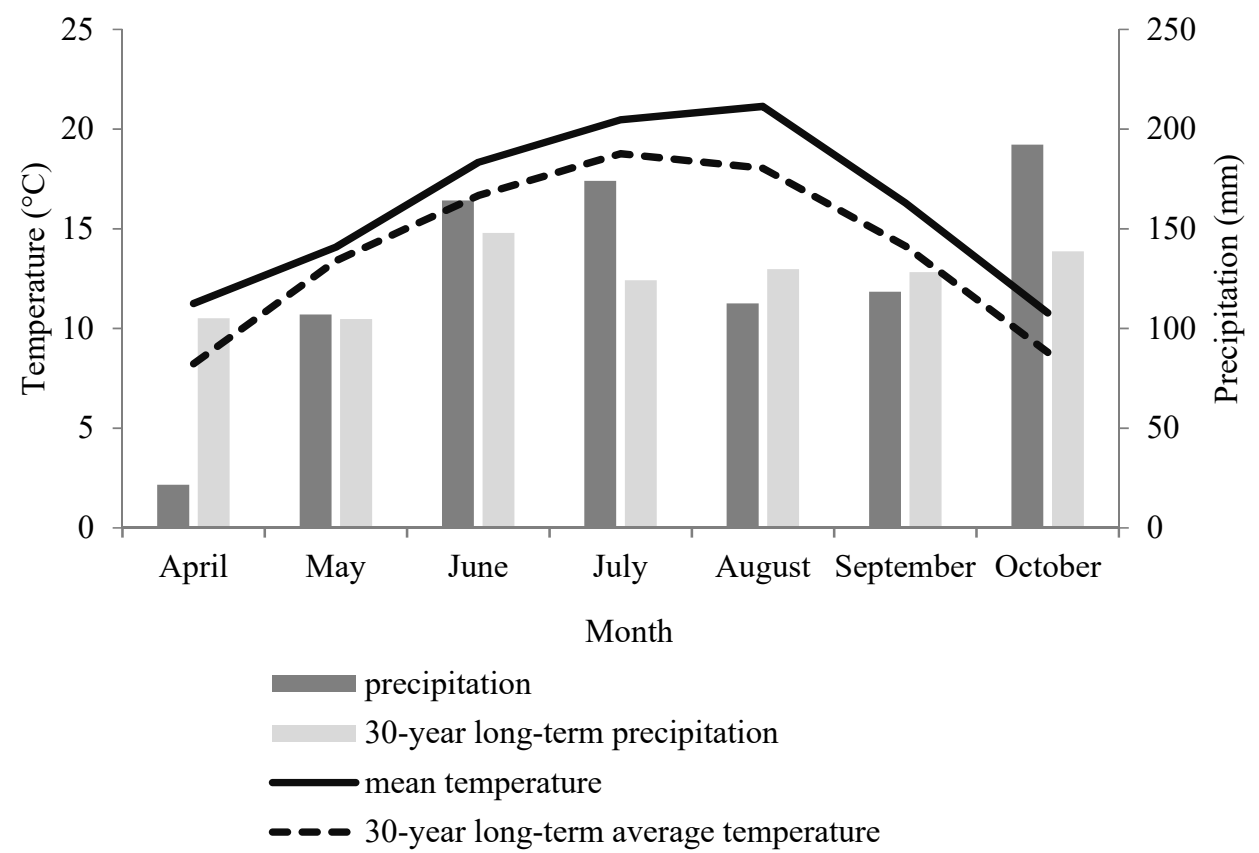

Figure 1. Mean temperature and precipitation for the experimental field in Jablje during 2020.

The berseem clover was terminated by frost in November 2019, and the soil was covered until spring of 2020 with a thick layer of dead plant residues. In 2020, the soil for the conventional tillage system was prepared with the plow (depth, $22 \mathrm{~cm} ; 17$ April 2020) and the furrows were closed with a drag leveling bar. Pre-sowing soil preparation was carried out on 7 May 2020, with a rotary harrow. For the conservation system, the soil was tilled with a disc harrow (depth, $8 \mathrm{~cm} ; 30$ April 2020). For the no-tillage system, the soil was left undisturbed. However, glyphosate was applied 10 days before sowing ( $2400 \mathrm{~g}$ a.i. ha ${ }^{-1}$; spray volume, $230 \mathrm{~L} \mathrm{ha}^{-1}$ ), to control perennial and winter annual weeds, and volunteer wheat seedlings.

The very early soybean variety 'Altona' (maturity group, 00 ) was sown with $18-\mathrm{cm}$ row spacing and a seed rate of 600,000 seeds ha ${ }^{-1}$. No additional inoculation with Rhizobium bacteria was performed. Soybean sowing was carried out on 22 May 2020, under optimal conditions, using a direct planting machine with high pressure on the seeding unit (Diretta; Maschio Gaspardo Campodarsego PD; Italy). Prior to the soybean sowing, basic fertilization with NPK fertilizer (6:12:24) was applied (380 $\left.\mathrm{kg} \mathrm{ha}^{-1}\right)$; no fertilizers were used after sowing.

To obtain uniform germination conditions, the entire experimental field was compacted with a Cambridge roller after sowing. One day after sowing (23 May 2020) a mixture of the active ingredients pendimethalin $\left(2500 \mathrm{~g} \mathrm{ha}^{-1}\right)$ and S-metolachlor $\left(1000 \mathrm{~g} \mathrm{ha}^{-1}\right)$ was applied (spray volume, $230 \mathrm{~L} \mathrm{ha}^{-1}$ ). Due to the favorable weather conditions with sufficient moisture, the herbicide mixture used was very effective, and no additional post-emergence weed control was required.

\subsection{Plant Sampling, Yield Assessment and Seed Analysis}

The plant sampling and measurements (i.e., height, number of branches, number of nodules and pods) were carried out on 20 August 2020, when soybeans reached the maximum pod filling stage (BBCH 77 [36]). Five soybean plants were randomly selected within each block for nodule assessment and below-ground and above-ground biomass (DM) production. The plants were excavated with the entire root clod, and the visible nodules were separated from the root system by hand. The rest of the nodules were 
removed from the roots by soaking in water. The individual plant parts and nodules were then dried at $60^{\circ} \mathrm{C}$ for 3 days, and the biomass (DM) was weighed. Shoot and root samples were analyzed for carbon and nitrogen content using the Dumas combustion method (Vario Max CN analyzer; Elementar Analysensysteme GmbH, Germany). Shoot and root C/N ratio was calculated based on shoot and root total carbon and total nitrogen contents, as given in Equation (1):

$$
\mathrm{C} / \mathrm{N}=(\text { Total C }(\%)) /(\text { Total N }(\%))
$$

Sampling for the soybean yield component was performed on 1 October 2020, with five plants randomly selected within each block to determine the number of the pods per plant. The soybean harvest for yield analysis was performed using a small plot harvester (Quantum; Wintersteiger AG Ried, Austria) on 9 October 2020, on two randomly assigned $30 \mathrm{~m}^{2}$ subplots within each block. After the harvest, the soybean seeds were dried at $30{ }^{\circ} \mathrm{C}$, and their nutritional composition was analyzed. Soybean crude fats, protein, fiber, and ash (mineral compounds) were determined using a spectrophotometer (Nir Tango-Bruker Optik GMBH, Gerhardt Analytical Systems device-Gerhardt Koenigswinter, Germany). Specific soil compaction was measured after the soybean harvest (14 October 2020), using a handheld hydraulic penetrometer (GKA 6860; Gouda Geo-Equipment B.V., The Netherlands), at a depth of 10 to $15 \mathrm{~cm}$ using a cone rod of diameter $1.28 \mathrm{~cm}$ and surface of $1.286 \mathrm{~cm}^{2}$, designed to measure heavier soil densities. The soil compaction was displayed by the manometer as specific soil resistance when the penetrometer tip penetrated the ground (i.e., Cl-Cone index, expressed in bars) [37]. The average soil moisture content from a depth of 0 to $15 \mathrm{~cm}$ was determined simultaneously with the soil compaction measurements, in close proximity to the hydraulic penetrometer sampling points. Soil moisture is expressed as volumetric water content, measured by the Time Domain Reflectometry method (Field Scout Soil Moisture Meter; Spectrum Technologies, Plainfield, IL, USA).

\subsection{Statistical Analysis}

All of the data were examined for homogeneity of variance using Levene's tests prior to the statistical analysis. These tests showed that the data were normally distributed, and no transformation was required. Soybean plant density, morphological parameters, yield and yield components, nutritional composition, and soil compaction data were then subjected to factorial analysis of variance (ANOVA), considering the tillage systems as main factors and the blocks as replicates. The means obtained by ANOVA were compared using post hoc Tukey's HSD tests, with a $p=0.05$ level of significance. Statistical analysis of the data was performed using the R program [38]. The relationships between the different variables were described using linear and non-linear regression models. Pearson's test for correlation $(p<0.05)$ between different soybean growth parameters and total nitrogen content and dry nodule mass was performed to show a relationship between these factors.

\section{Results and Discussion}

\subsection{Soybean Growth Parameters and Biomass Production}

Soybean growth and development were significantly affected by the tillage systems, for all of the study parameters. In particular, the plant density, plant height, and number of nodes and branches differed significantly between the three tillage systems (Table 1). The highest plant density was for the conventional system (56.0 plants $\left.\mathrm{m}^{-2}\right)$, while the lowest plant density was for the no-tillage system (35.2 plants $\left.\mathrm{m}^{-2}\right)$. Soybean production using a no-tillage system is often less successful in poorly drained soils [39], in part because of the cooler and wetter soil conditions at planting [40]. Such soil conditions can lead to slower soybean germination and emergence, which makes the seedlings more vulnerable to seedling diseases. Ref. [41] also reported their highest plant density for conventionally tilled soil (49 plants $\mathrm{m}^{-2}$ ), which was decreased for their no-tillage system (36 plants $\mathrm{m}^{-2}$ ). The main reason for decreased soybean stands in the present study was the lower germination and establishment rates for the conservation and no-tillage systems. Although professional no-tillage seeding equipment was used, which allowed high down pressure 
per seeding unit, the upper soil layer was compacted during the sowing. Therefore, a portion of the seeds was not adequately covered with fine soil for the no-tillage system, and to lesser extent also for the conservation system.

Table 1. Growth parameters for the soybean plants according to the different tillage systems.

\begin{tabular}{ccccc}
\hline Tillage System & $\begin{array}{c}\text { Plant Density } \\
\left(\mathbf{m}^{-\mathbf{2}}\right)\end{array}$ & Plant Height $\mathbf{( c m )}$ & $\begin{array}{c}\text { Number of Nodes } \\
\text { Plant }^{-1}\end{array}$ & $\begin{array}{c}\text { Number of } \\
\text { Branches Plant }^{-1}\end{array}$ \\
\hline Conventional & $56.0 \pm 1.4 \mathrm{c}$ & $106.5 \pm 2.4 \mathrm{~b}$ & $17.1 \pm 0.4 \mathrm{~b}$ & $5.8 \pm 0.4 \mathrm{~b}$ \\
Conservation & $47.4 \pm 1.4 \mathrm{~b}$ & $117.9 \pm 1.6 \mathrm{c}$ & $15.3 \pm 0.3 \mathrm{a}$ & $2.2 \pm 0.2 \mathrm{a}$ \\
No-tillage & $35.2 \pm 1.4 \mathrm{a}$ & $95.8 \pm 1.8 \mathrm{a}$ & $15.8 \pm 0.3 \mathrm{a}$ & $6.1 \pm 0.5 \mathrm{~b}$ \\
\hline
\end{tabular}

Data are the means \pm standard errors. Data with different letters within columns indicate significant differences $(p \leq 0.05$, Tukey's tests).

The soybean plants for the conservation system reached $117.9 \mathrm{~cm}$ in height, which was significantly greater than both the conventional $(106.5 \mathrm{~cm})$ and no-tillage $(95.8 \mathrm{~cm})$ systems. Conventional tillage can improve the water-air regime and the mobility of minerals in the deeper soil layers and has been shown to increase soybean plant height compared to no-tillage [42,43]. For no-tillage systems, soybean growth can be inhibited by the soil compaction, which reduces the root density and absorption efficiency at greater soil depths [30].

The nodes per plant in the present study was significantly higher for the conventional system (17.1 nodes per plant), while similar values were seen between the conservation and no-tillage systems (15.3, 15.8 nodes per plant, respectively). Ref. [44] also observed more nodes on soybean plants from conventionally cultivated soil compared to those from shallow-tilled soil. Although the soybean density for the no-tillage system in the present study was the lowest, these plants showed similar numbers of branches to the conventional system (6.1 and 5.8 branches per plant, respectively). This was not expected, as the plant density and intraspecific competition in both the conservation and no-tillage systems were reduced, which would thus allow the plants to show stronger lateral growth. Ref. [41] also noted more plant branching for less intensive soil tillage and indicated positive effects on the side-shoot development. The linear correlations shown in Figure 2 show that plant height and plant density, and number of nodes per plant and plant height, were positively correlated (33.8\%; $p=0.008$ and 5.7\%; $p=0.664$, respectively), whereas the number of branches were negatively correlated with plant density $(-8.4 \% ; p=0.523)$.

These tillage systems also had significant effects on soybean shoot and root dry matter (DM) production (Figure 3). The greatest mean shoot DM per plant was seen for the conventional system ( $\left.65.5 \mathrm{~g} \mathrm{plant}^{-1}\right)$, and the lowest for the conservation system $(35.6 \mathrm{~g}$ plant $\left.^{-1}\right)$, with the no-tillage system at an intermediate level (51.6 g plant $\left.^{-1}\right)$. The greatest root DM was also seen for the soybean plants grown under the conventional system $(6.2 \mathrm{~g}$ plant $\left.^{-1}\right)$; this was not significantly different from that for the no-tillage system (5.5 $\mathrm{g}$ plant $\left.^{-1}\right)$, and these were both significantly greater than for the conservation system ( $3.5 \mathrm{~g}$ plant $\left.^{-1}\right)$. Refs. $[26,45]$ and showed that alternative tillage systems improved both soil biological characteristics and plant growth. These findings agree with the present study, where shoot and root DM in the no-tillage system were significantly greater than the conservation tillage system. According to [26], improved crop growth with no-tillage is related to several factors, including higher soil moisture, lower soil temperature, permanence of soil aggregates, and higher soil carbon content. 

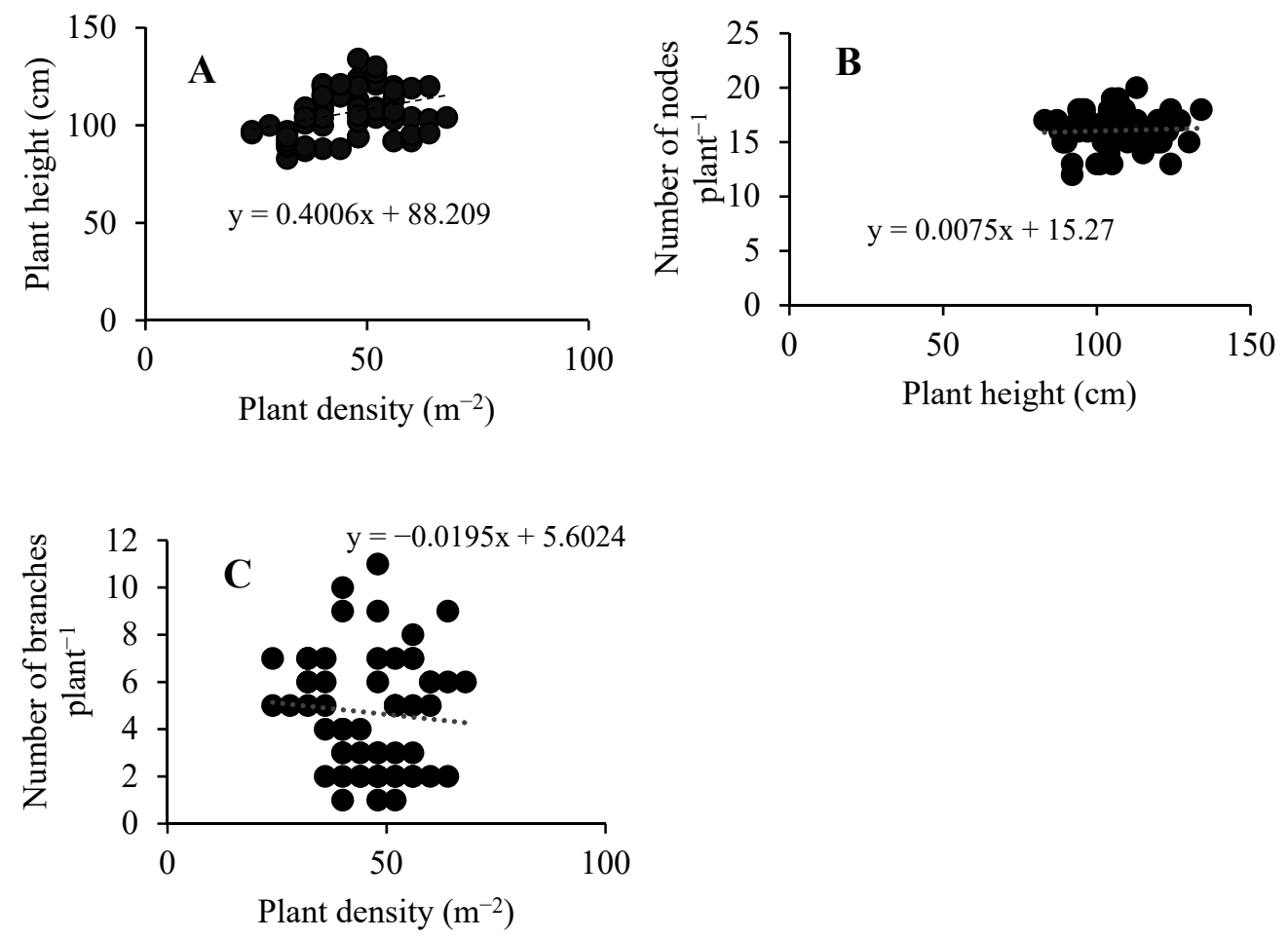

Figure 2. Linear correlations between plant density and plant height (A), plant height and number of nodes (B), and plant density and number of branches (C).

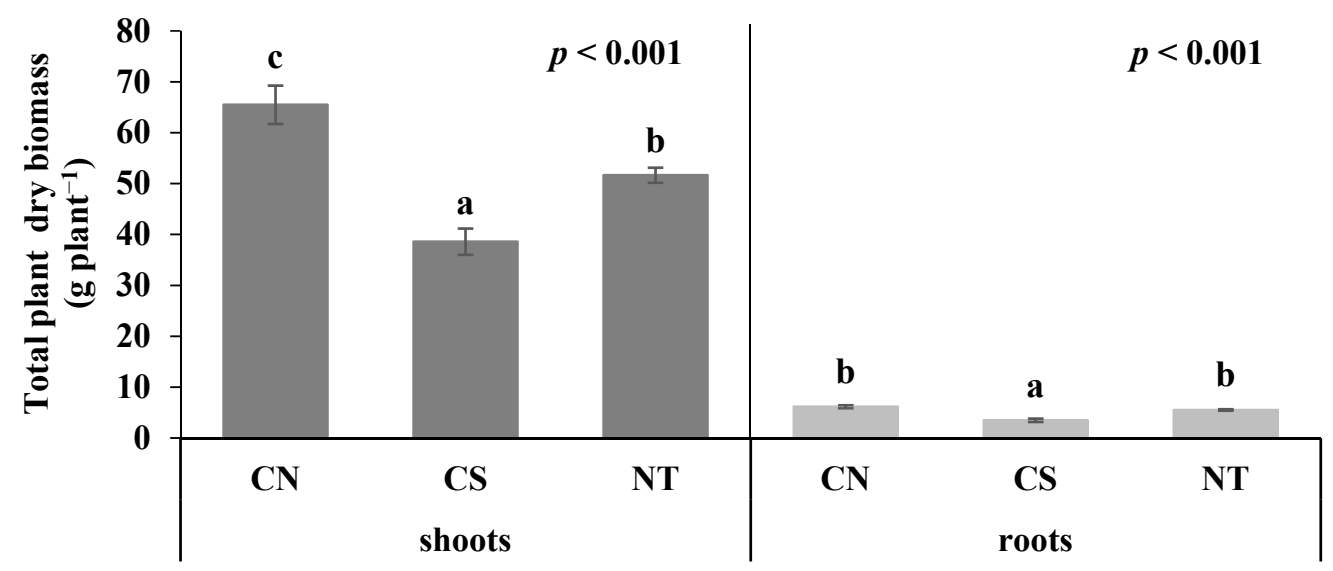

Figure 3. Soybean shoot and root production according to the different tillage systems (CN, conventional; CS, conservation; NT, no-tillage). Data are the means \pm standard error. Different letters ( $a, b$, c) indicate significant differences ( $p \leq 0.05$, Tukey's tests) among treatments.

\subsection{Soybean Yield Components and Dry Seed Production}

These tillage systems also showed significant differences for mean number of pods per plant, number of pods per unit area $\left(\mathrm{m}^{-2}\right)$, and 100-seed mass $(p<0.001)$. The greatest number of pods per plant was for the conventional system (103.6 pods plant $\left.{ }^{-1}\right)$, while the lowest was for the conservation system (only 46.5 pods plant $^{-1}$ ) (Table 2). The greatest pod number was seen for the conventional system (5799 pods $\mathrm{m}^{-2}$ ), with significantly lower pod numbers for the conservation and no-tillage systems (2206 and 2547 pods $\mathrm{m}^{-2}$, respectively) (Table 2). Ref. [46] also reported that their conventional and reduced tillage systems showed greater pod numbers per plant compared to their no-tillage system. The 100 -seed mass for the conventional system $(19.7 \mathrm{~g})$ was significantly greater than for the conservation and no-tillage systems, which were similar (17.3 and $16.4 \mathrm{~g}$, respectively) (Table 2). Indeed, such tillage systems have been shown to have relevant effects on absolute 
seed mass [47], while [48] reported that their conventional system favored soybean seed size (as 1000-seed mass) over their no-tillage system. However, [25] showed lower soybean 100 -seed mass $(11.4 \mathrm{~g})$ than the present study and reported no effects of their tillage systems on soybean seed size. Then, in contrast to both the present and [25] study, [49] showed greater seed mass for their no-tillage system, with their effects of plant density on seed weight not consistent across the 4-year study.

Table 2. Soybean yield components according to the different tillage systems.

\begin{tabular}{cccccc}
\hline $\begin{array}{c}\text { Tillage } \\
\text { System }\end{array}$ & $\begin{array}{c}\text { Number of } \\
\text { Pods Plant }^{-\mathbf{1}}\end{array}$ & $\begin{array}{c}\text { Number of Pods } \\
\mathbf{m}^{-\mathbf{2}}\end{array}$ & $\begin{array}{c}\text { 100-Seed } \\
\text { Mass (g) }\end{array}$ & $\begin{array}{c}\text { First Pod } \\
\text { Height (cm) }\end{array}$ & $\begin{array}{c}\text { Dry Seed } \\
\left.\text { Yield (t ha }^{-\mathbf{1}}\right)\end{array}$ \\
\hline Conventional & $103.6 \pm 7.4 \mathrm{c}$ & $5798.8 \pm 414.7 \mathrm{~b}$ & $19.7 \pm 0.3 \mathrm{~b}$ & $15.1 \pm 5.9 \mathrm{a}$ & $4.54 \pm 0.1 \mathrm{a}$ \\
Conservation & $46.5 \pm 4.4 \mathrm{a}$ & $2206.5 \pm 101.1 \mathrm{a}$ & $17.3 \pm 0.8 \mathrm{a}$ & $17.4 \pm 3.1 \mathrm{a}$ & $4.48 \pm 0.2 \mathrm{a}$ \\
No-tillage & $72.3 \pm 2.1 \mathrm{~b}$ & $2546.7 \pm 156.3 \mathrm{a}$ & $16.4 \pm 0.4 \mathrm{a}$ & $13.1 \pm 7.5 \mathrm{a}$ & $4.00 \pm 0.2 \mathrm{a}$ \\
\hline
\end{tabular}

Data are the means \pm standard errors. Data with different letters within columns indicate significant differences ( $p \leq 0.05$, Tukey's tests).

Although in the present study the heights of the first pods (Table 2) were related to the heights of the soybean plants (Table 1), there were no significant differences in first pod heights between the tillage systems. The numerically greatest first pod height was seen for the conventional system $(17.4 \mathrm{~cm})$ and the numerically lowest for the no-tillage system $(13.1 \mathrm{~cm})$. Soybean seed loss during harvesting is a major problem, and this has been related to first pod height $[50,51]$. First pod height is affected by the genetic structure, cultivation processes, and precipitation or irrigation levels [52]. Ref. [53] reported that seed losses were avoided when the first pod height was $>20 \mathrm{~cm}$; however, the first pods height should not be greater than the height of the cutter bar of the combine harvester; most frequently reported first pod height is between 10 and $12 \mathrm{~cm}$.

Soybean dry seed yields were similar between the tillage systems in the present study (range between 4.00 and $4.54 \mathrm{t} \mathrm{ha}^{-1}$ ) (Table 2). Indeed, consideration of the soybean yield components here demonstrates the highly flexible nature of this legume crop. Compared to the conventional system, the conservation system had lower plant density, produced half the number of pods per plant, and had about 10\% lower 100-seed mass, which suggested greater numbers of seeds in the pods for the conservation system.

In the literature, there are inconsistent data on the effects of soil tillage systems on soybean seed yields, probably due to differences in soil and environmental conditions across the relevant studies. Under more arid climatic conditions in particular, soybean yields for a no-tillage system can be increased, which was reported as due to better crop emergence and establishment, and/or to greater retention of soil moisture [54]. Studies performed in more humid climates are in line with the numerical trend in the present study of greater soybean seed yields for the tilled systems. The main contributing factors identified for greater soybean yields for conventional tillage were the beneficial effects of tillage on soil structure, porosity, infiltration rate, and nutrient absorption [41,43]. Moreover, some studies have indicated that for no-tillage systems, soybean yield can be reduced due to lower nitrogen availability and/or lower soil temperature, because of the greater soil coverage by the crop residues compared to a conventional system $[40,55]$.

\subsection{Soybean Nodule Production}

The data for the mean numbers of nodules on the tap and lateral roots are given in Table 3. The tillage system had a significant effect on the number of nodules per plant for the tap roots $(p=0.0069)$, although not for the lateral roots $(p=0.2388)$. The greatest nodule production for the tap root of the individual soybean plants was seen for the conventional and no-tillage systems (11.3 and 8.8 nodules plant ${ }^{-1}$, respectively); these were significantly higher than for the conservation system (4.3 nodules plant $\left.{ }^{-1}\right)$. Although the nodule development on the lateral roots were not significantly different between the tillage treatments, these followed the same pattern of nodule production on the tap root (Table 3). Across the tillage systems, the numbers of large-sized nodules (diameter $>4 \mathrm{~mm}$ ) 
on the tap roots were not significantly different $(p=0.2761)$, contrary to that seem for the lateral roots $(p=0.0102)$. The large-sized nodules on the tap roots were numerically similar for the conventional and the no-tillage systems (5.7 and 4.8 nodules $>4 \mathrm{~mm}$ plant $^{-1}$ ) and tended to be lower for the conservation system ( 2.4 nodules $\left.>4 \mathrm{~mm} \mathrm{plant}^{-1}\right)$. For the lateral roots, most of the large-sized nodules were seen for the conventional system (12.0 nodules $>4 \mathrm{~mm}_{\text {plant }}{ }^{-1}$ ), with significantly fewer for the conservation system (1.0 nodule $>4 \mathrm{~mm}$ plant $\left.^{-1}\right)$. Here, the no-tillage system produced an intermediate number of large-sized nodules on the lateral roots (Table 3 ).

Table 3. Soybean nodule production according to the different tillage systems.

\begin{tabular}{ccccc}
\hline Tillage & \multicolumn{2}{c}{ Tap Root } & \multicolumn{2}{c}{ Lateral Roots } \\
\hline System & $\begin{array}{c}\text { Number of } \\
\text { Nodules Plant }^{-1}\end{array}$ & $\begin{array}{c}\text { Number of } \\
\text { Nodules }>\mathbf{4} \text { mm } \\
\text { Plant }^{-1}\end{array}$ & $\begin{array}{c}\text { Number of } \\
\text { Nodules Plant }^{-1}\end{array}$ & $\begin{array}{c}\text { Number of } \\
\text { Nodules }>\mathbf{4} \text { mm } \\
\text { Plant }^{-1}\end{array}$ \\
\hline Conventional & $11.3 \pm 1.3 \mathrm{~b}$ & $5.0 \pm 1.1 \mathrm{a}$ & $92.6 \pm 18.6 \mathrm{a}$ & $12.0 \pm 2.5 \mathrm{~b}$ \\
Conservation & $4.3 \pm 1.6 \mathrm{a}$ & $2.4 \pm 0.5 \mathrm{a}$ & $53.4 \pm 11.8 \mathrm{a}$ & $1.0 \pm 3.6 \mathrm{a}$ \\
No-tillage & $8.8 \pm 1.4 \mathrm{~b}$ & $4.9 \pm 0.7 \mathrm{a}$ & $83.5 \pm 12.1 \mathrm{a}$ & $5.7 \pm 3.6 \mathrm{ab}$ \\
\hline
\end{tabular}

Data are the means \pm standard errors. Data with different letters within columns indicate significant differences $(p \leq 0.05$, Tukey's tests).

Due to the significant differences in the plant densities across these tillage systems, nodule production per plant was also expressed per unit area $\left(\mathrm{m}^{-2}\right)$. Analysis of these data showed generally analogous effects across the tillage systems as seen for nodule production per plant (data not shown). Thus, again, there were significant effects of these tillage systems for the number of nodules $\mathrm{m}^{-2}$ on the tap roots $(p=0.023)$, while this did not reach significance for the lateral roots $(p=0.089)$. Additionally, like the measure of the large-sized (diameter $>4 \mathrm{~mm}$ ) nodules per plant, for the large-sized nodules $\mathrm{m}^{-2}$ the tillage systems had a significant effect for the lateral roots $(p=0.0084)$. Instead, for the tap roots, when these data were expressed per plant, they did not differ significantly between the tillage treatments, significant differences were seen for these large-sized nodules when expressed per unit area for the tap roots $(p=0.0155)$. Furthermore, significantly more large-size nodules were seen for the conventional system $\left(280\right.$ nodules $\left.\mathrm{m}^{-2}\right)$ compared to the conservation system (113.8 nodules $\mathrm{m}^{-2}$ ) and no-tillage $\left(172.5\right.$ nodules $\left.\mathrm{m}^{-2}\right)$.

These data are in line with the study of [30], where the numbers of effective nodules on the roots increased with increasing tillage depth. In contrast, [56] reported greater nodule development on soybean grown in medium-shallow tilled soil (depth 12-14 cm), compared to medium-deep tilled soil (depth 14-16 cm). The nodules that are formed on the lateral roots are the result of the existing bacteria in the soil, while the nodulation of already infested roots results in a high number of small nodules with decreased densities of bacteroides and decreased nitrogen fixation [1]. Indeed, the nitrogen-fixing activities of root nodules are closely related to their size, whereby larger nodules have a greater proportion of Rhizobium-infected area and show higher nitrogen-fixing activity [57]. Ref. [28] also reported that larger nodules (diameter $>4 \mathrm{~mm}$ ) on soybean root have greater nitrogen-fixing activity than small ones (diameter $<2 \mathrm{~mm}$ ). Nitrogen-fixing activities can change with the nodule development stages, although due to their quantity, it is the numbers of mediumsized nodules that eventually determine the overall amount of nitrogen fixation [28].

These tillage systems had significant effects on the dry nodule mass plant ${ }^{-1}(p=0.01)$. Here, the conventional system ( $\left.1.1 \mathrm{~g} \mathrm{plant}^{-1}\right)$ was significantly higher than both the conservation and no-tillage systems ( 0.5 and 0.7 g plant $^{-1}$, respectively) (Figure 4$)$. These tillage systems also had significant effects on the dry nodule mass $\mathrm{m}^{-2}(p=0.0007)$, which was again greatest for the conventional system $\left(61.6 \mathrm{~g} \mathrm{~m}^{-2}\right)$, and significantly lower for the conservation and no-tillage systems (23.7 and $\left.24.6 \mathrm{~g} \mathrm{~m}^{-2}\right)$. 


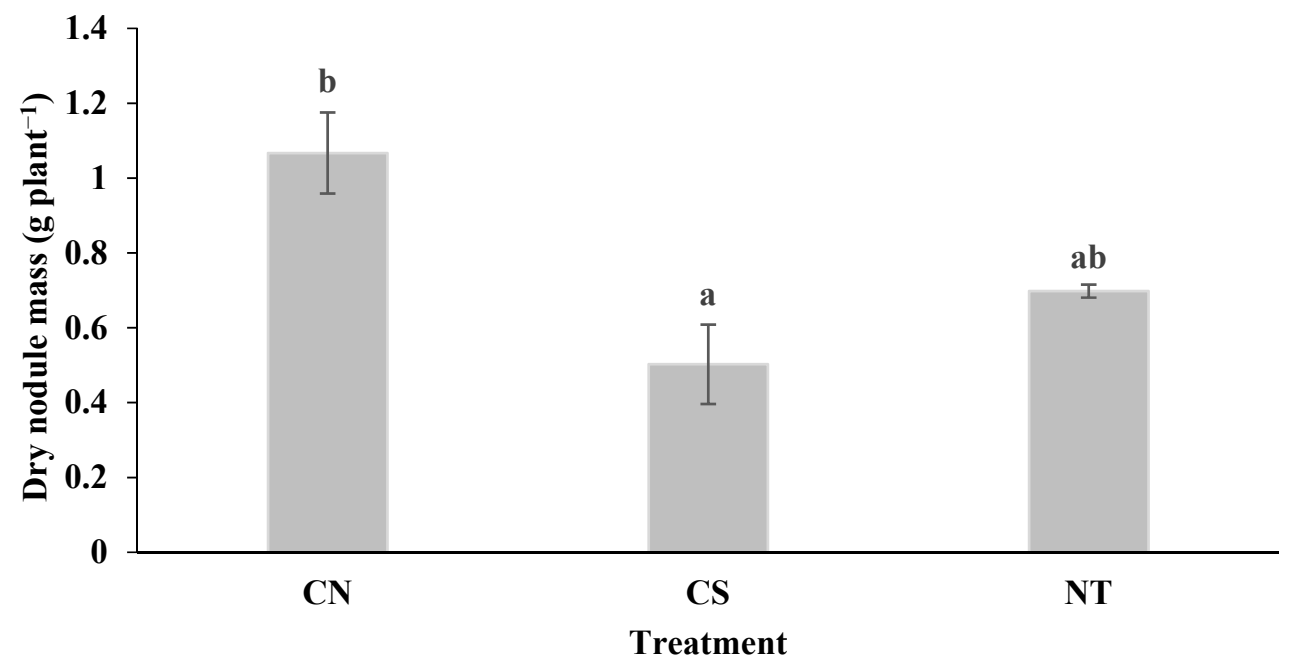

Figure 4. Soybean dry nodule mass production per plant according to the different tillage systems ( $\mathrm{CN}$, conventional; $\mathrm{CS}$, conservation; NT, no-tillage). Data are the means \pm standard error. Different letters $(a, b, a b)$ indicate significant differences $(p \leq 0.05$, Tukey's tests) among treatments.

A no-tillage system promotes an ecological environment that is different from a conventional system, especially in the first centimeters of soil depth, where decreased temperature fluctuations and increased moisture can promote microbial activity [58]. These benefits are also observed in the Rhizobium-legume symbiosis with enhanced nodule development at greater soil depth. Furthermore, cell numbers, nodule production, and diversity of Bradyrhizobium are also increased, thus providing greater rates of biological nitrogen fixation [59].

Hanhur et al. [56] argued that among other factors, the number and mass of symbiotic nodules are mainly influenced by soil moisture, gas exchange between the soil and the environment, and soil temperature. Increased nodule development has also been linked to the sensitivity of Rhizobium bacteria to soil desiccation and light, with no-tillage systems characterized by greater water retention capacity of the soil. Furthermore, due to the absence of tillage in this system, there is also less evaporation of water from the soil. No-tillage systems also promote the greater contents of organic carbon and macronutrients in the soil, which represent sources of nutrients for microorganisms [60]. The reason for the greater dry mass of the nodules for the conventional system in the present study might therefore be related to the less-compacted soil and the good water-air regime. Furthermore, the favorable environmental conditions here of moderate summer temperatures and abundant rainfall in the 2020 season will have reduced the differences in water availability between the tillage systems.

\subsection{Nitrogen and Carbon Content in Soybean Shoots and Roots}

The nitrogen contents in the shoots and roots were not significantly affected by the tillage systems ( $p=0.187$ and 0.204 , respectively), as for the carbon content in the roots $(p=0.0681)$. However, the carbon content in the shoots was significantly influenced by the tillage system $(p=0.0205)$. Overall, the nitrogen content in the shoots was about twice that in the roots ( $2.6 \%$ vs. $1.2 \%$, respectively), while the carbon content was similar for shoots and roots. The carbon content in the shoots was slightly, but significantly, higher for the conventional system $(43.2 \%)$ compared to both the conservation and no-tillage systems (42.4\% and $42.3 \%$, respectively) (Table 4 ). 
Table 4. Total nitrogen and carbon contents in soybean shoots and roots according to the different tillage systems.

\begin{tabular}{cccc}
\hline Plant Part & Tillage System & Total N Content (\%) & Total C Content (\%) \\
\hline Shoots & Conventional & $2.8 \pm 0.1 \mathrm{a}$ & $43.2 \pm 0.3 \mathrm{~b}$ \\
& Conservation & $2.6 \pm 0.1 \mathrm{a}$ & $42.4 \pm 0.2 \mathrm{a}$ \\
& No-tillage & $2.5 \pm 0.2 \mathrm{a}$ & $42.3 \pm 0.1 \mathrm{a}$ \\
\hline \multirow{2}{*}{ Roots } & Conventional & $1.4 \pm 0.1 \mathrm{a}$ & $41.4 \pm 0.5 \mathrm{a}$ \\
& Conservation & $1.2 \pm 0.1 \mathrm{a}$ & $42.6 \pm 0.2 \mathrm{a}$ \\
& No-tillage & $1.1 \pm 0.1 \mathrm{a}$ & $42.5 \pm 0.2 \mathrm{a}$ \\
\hline
\end{tabular}

Data are the means \pm standard errors. Data with different letters within columns indicate significant differences ( $p \leq 0.05$, Tukey's tests)

There was a positive linear correlation $(70.8 \% ; p=0.01)$ between total nitrogen content in the roots and dry nodule mass (Figure 5). The numerically (although not significantly) greatest nitrogen content in the roots for the conventional system was associated with the (significantly) greatest dry nodule mass (Figure 5). In contrast to these data for the shoot and root nitrogen contents, several other studies have shown high amounts of fixed nitrogen for soybean for no-tillage systems, where there is minimal soil disturbance and more rhizobial activity and nitrogen fixation [26,61].

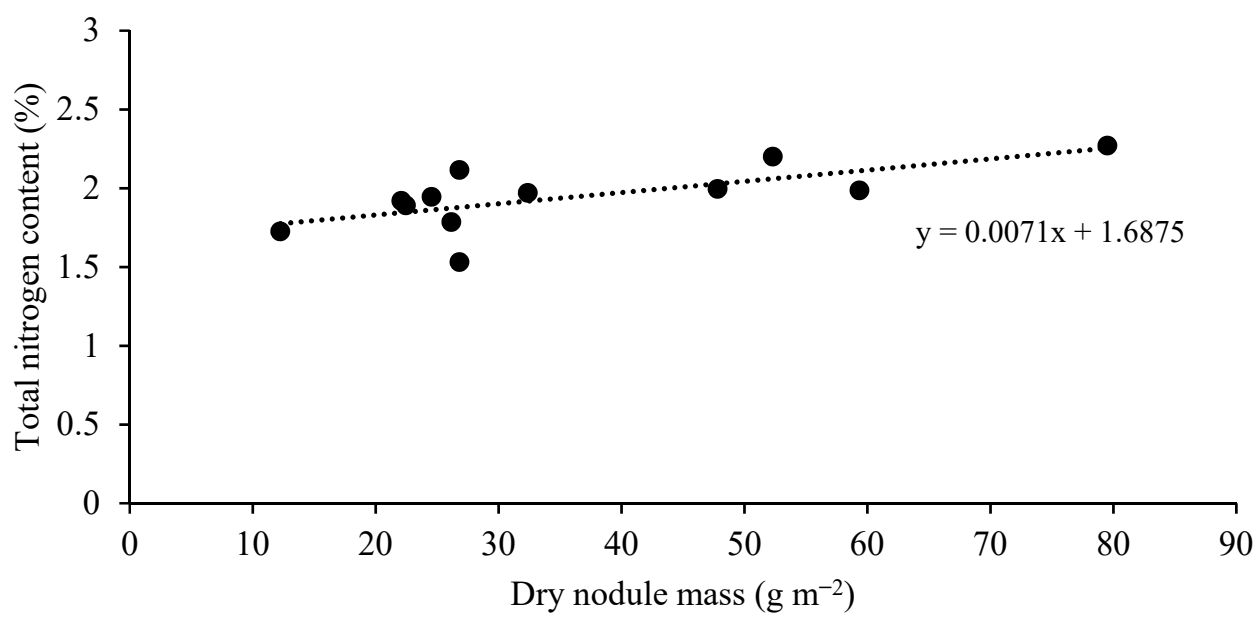

Figure 5. Linear correlation between total nitrogen content and dry nodule mass of the soybean roots.

The tillage systems had no significant effects on the $\mathrm{C} / \mathrm{N}$ ratio in either the shoots $(p=0.131)$ or roots $(p=0.251)$ (Figure 6). Indeed, the differences in the $\mathrm{C} / \mathrm{N}$ ratios for the shoots were minor, although the no-tillage system showed indications of being higher (17.4). For the roots, there were larger differences in the $\mathrm{C} / \mathrm{N}$ ratio, although these did not reach significance; numerically, the conservation system was the highest (37.3), and the conventional system was the lowest. Soybean residues generally contain low $\mathrm{C} / \mathrm{N}$ ratios (15-41), and thus its residues can be mineralized faster, without soil microbes tying up the inorganic nitrogen in the process (i.e., nitrogen immobilization) [62,63]. The nitrogen credit from soybean residues arises from the effects of the residue decomposition on the inorganic nitrogen pool, and not from the fixed nitrogen from the root nodules. This increases the plant-available nitrogen in the soil system for the following crop without the need for any nitrogen fertilizer input. 


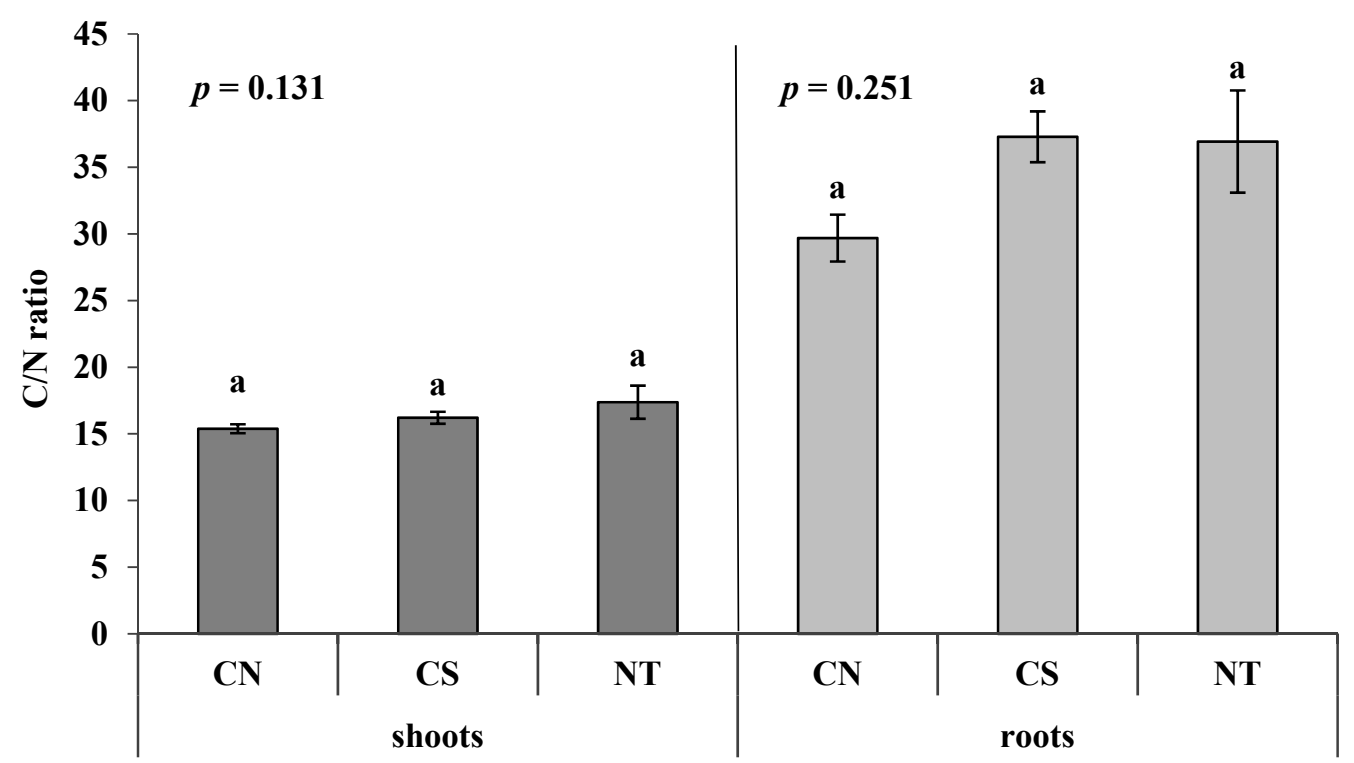

Figure 6. Soybean shoot and root $\mathrm{C} / \mathrm{N}$ ratios according to the different tillage systems $(\mathrm{CN}$, conventional; CS, conservation; NT, no-tillage). Data are the means \pm standard error. Letters (a) indicate nonsignificant differences ( $p \leq 0.05$, Tukey's tests) among treatments.

\subsection{Nutritional Composition of Soybean Seeds}

Significant differences between the tillage systems were seen for the crude protein content $(p=0.00112)$, while there were no significant differences for the crude fat, fiber, and ash (Table 5).

Table 5. Nutritional composition of the soybean seeds according to the different tillage systems.

\begin{tabular}{cccccc}
\hline $\begin{array}{c}\text { Tillage } \\
\text { System }\end{array}$ & $\begin{array}{c}\text { Dry Matter } \\
\left(\mathbf{g ~ k g}^{-\mathbf{1}} \mathbf{F W}\right)\end{array}$ & $\begin{array}{c}\text { Crude Fats } \\
\left(\mathbf{g ~ k g}^{-\mathbf{1}} \mathbf{~ D M}\right)\end{array}$ & $\begin{array}{c}\text { Crude Protein } \\
\left(\mathbf{g ~ k g}^{-\mathbf{1}} \mathbf{~ D M}\right)\end{array}$ & $\begin{array}{c}\text { Crude Fiber } \\
\left.\mathbf{( g ~ k g}^{-\mathbf{1}} \mathbf{~ D M}\right)\end{array}$ & $\begin{array}{c}\text { Crude Ash }^{\mathbf{a}} \\
\left.\mathbf{( g ~ k g}^{-\mathbf{1}} \mathbf{~ D M}\right)\end{array}$ \\
\hline Conventional & $944 \pm 0.9 \mathrm{a}$ & $190 \pm 2.3 \mathrm{a}$ & $371 \pm 2.1 \mathrm{~b}$ & $54 \pm 0.6 \mathrm{a}$ & $56 \pm 0.5 \mathrm{a}$ \\
Conservation & $943 \pm 0.7 \mathrm{a}$ & $186 \pm 1.7 \mathrm{a}$ & $371 \pm 3.6 \mathrm{~b}$ & $54 \pm 0.6 \mathrm{a}$ & $54 \pm 0.3 \mathrm{a}$ \\
No-tillage & $943 \pm 0.5 \mathrm{a}$ & $189 \pm 1.7 \mathrm{a}$ & $354 \pm 3.4 \mathrm{a}$ & $55 \pm 0.7 \mathrm{a}$ & $55 \pm 0.4 \mathrm{a}$ \\
\hline
\end{tabular}

Data are the means \pm standard errors. FW, fresh weight; DM, dry matter. ${ }^{a}$ Crude ash of the mineral compounds Data with different letters within columns indicate significant differences ( $p \leq 0.05$, Tukey's tests).

Soybean seeds usually contain 180 to $220 \mathrm{~g} \mathrm{~kg}^{-1}$ crude fat [64]. In the present study, this varied from $186 \mathrm{~g} \mathrm{~kg}^{-1}$ for the conservation system to $190 \mathrm{~g} \mathrm{~kg}^{-1}$ for the conventional system. The mean crude protein in these samples ranged from the significantly lower no-tillage system at $354 \mathrm{~g} \mathrm{~kg}^{-1} \mathrm{DM}$, to the same value for the other two tillage systems of $371 \mathrm{~g} \mathrm{~kg}^{-1} \mathrm{DM}$. Protein content in leguminous plants can be influenced by several factors, including variety, climatic conditions, and management factors (e.g., nitrogen fertilization), and therefore significant variations are seen between studies in the literature [65]. Ref. [66] reported higher protein contents, which varied from $404 \mathrm{~g} \mathrm{~kg}^{-1}$ for their conventional system, to $418 \mathrm{~g} \mathrm{~kg}^{-1}$ for no-tillage system. Higher protein contents have also been attributed to the cropping system, although lower fat content was shown compared to soybean grown in monoculture [3]. Ref. [50] reported that the protein content was also influenced by plant density. This is in line with the present study, where significantly lower protein content was seen for the no-tillage system (Table 5), where there was significantly lower plant density (Table 1). For the mean contents of crude fiber, these soybean seeds showed little, if any, variation (54-55 $\left.\mathrm{g} \mathrm{kg}^{-1} \mathrm{DM}\right)$. Ref. [3] concluded that the greatest fiber content was observed in years with high temperatures and moderate precipitation throughout the growing season. Soybean is also a good source of minerals. The nutritional composition of soybean seeds is affected by the type of crop management, tillage system, soil, and climatic conditions [67]. In the present study, the mean content of mineral 
compounds in the form of ash did not vary significantly between the tillage systems (54-56 $\left.\mathrm{g} \mathrm{kg}^{-1} \mathrm{DM}\right)$.

\subsection{Soil Compaction and Soil Moisture Content}

Soil compaction is a result of the natural soil aggregation processes as well as the differences in the intensities of the tillage operations. Soil moisture content is the most important factor in the process of soil compaction [68]. As the soil moisture content increased, the effectiveness and depth of compaction increased significantly [69]. The measurement with a hand-held hydraulic penetrometer showed that the tillage systems had significant effects on the soil compaction $(p<0.001)$. The greatest soil compaction was seen for the no-tillage system ( 16.9 bar), followed by the conservation and conventional systems (13.7, 10.5 bar, respectively). Soil moisture (expressed as volumetric water content) was also significantly different between the tillage systems $(p>0.05)$. The soil moisture for conventional tillage (19.7\%) was significanty lower than the conservation $(24.1 \%)$ and no-tillage $(26.8 \%)$ systems.

Indeed, conventional tillage changes the structure of the soil. It reduces the soil resistance to penetration and increases the numbers of micropores and the soil porosity, while also improving the water retention capacity of the soil [70]. Soil compaction in the present study reduced plant establishment after sowing, which resulted in major differences in the plant densities between the tillage systems (Table 1). Consequently, the precise influence of soil compaction itself, when isolated from the overall effects of the tillage systems, cannot be determined in the present study, as the soybean growth responses and individual plant performances were affected by the differences in the plant stands.

\section{Conclusions}

Modern arable production is facing major challenges, with recent reports showing that soil degradation has become an increasingly serious threat. Extensive global changes in tillage practices started some 25 years ago with the introduction of the first herbicidetolerant GM soybean, which was then joined by other GM crops in the following years. Both soybean production and the area under alternative tillage systems in Europe are steadily increasing; however, the main drivers are not related to the expansion of GM crops. Instead, European farmers are adopting conservation and no-tillage systems mainly to improve their economic performance, and to a lesser extent also to address environmental issues related to the current unsustainable crop management practices.

The data from the present field study carried out during the early conversion stages from conventional to conservation and no-tillage systems showed that all of the soybean growth and yield parameters determined were affected by these changes in tillage practices. The plant density, number of nodes, shoot and root DM, and number of pods per plant and per unit area were all highest for the reference conventional tillage system. Although the transition of tilled cropland to conservation and no-tillage systems delivers numerous benefits, reduced crop yields can occur in the period before the improvement of the soil properties. This was not the case in the present study, as particularly high soybean dry seed yields of around $4.5 \mathrm{tha}^{-1}$ were obtained for both the conventional and conservation tillage systems. Indeed, a relatively small yield decrease was seen for the no-tillage system (to $4.0 \mathrm{tha}^{-1}$ ), because of the considerable soil compaction that reduced germination and early plant establishment. The high levels of soybean productivity and the relatively small yield differences between the tillage treatments here was facilitated by the favorable weather conditions, where there was sufficient supply of moisture and high initial soil content of organic matter. Consequently, the benefits of greater soil water retention and soil organic matter build-up for less intensive tillage practices would probably not become apparent in such a short conversion period as used here. The data for the soybean growth parameters showed that soybean is a highly adaptable crop that can compensate for considerable plant stand loss, as there was only a minor decrease in the yield for the no-tillage system even when the plant density was substantially reduced. 
Although the levels of nitrogen fixation in the present study were not directly assessed, the soybean nitrogen-fixing capacity can be estimated according to the numbers and sizes of the nodules that develop on soybean roots. Regardless of being measured per plant or per area, the soybean under the conventional system showed the greatest number and DM of nodules, as well as the greatest proportion of large-sized nodules (diameter $>4 \mathrm{~mm}$ ) for both the tap and lateral roots. The assumption of increased nitrogen fixation in the conventional system is further supported on the basis that the conventional system also showed the greatest shoot and root nitrogen contents. Furthermore, the soybean dry nodule mass was positively correlated with the root nitrogen content.

Increasing demand for high-protein feed for animals is boosting soybean production in Europe, even in the less suitable central and northern production areas. Currently, the majority of soybean in Europe is produced using 3- or 4-year crop rotation practices with the conventional tillage system. With the expansion of areas under alternative tillage systems, it is likely that increasingly more soybeans will be produced using such alternative tillage systems. Indeed, this field experiment could be conducted over only 1 year due to the soybean crop rotation restrictions. However, the results of the present study suggest that soybean can be an important part of crop rotation in northern production areas and can provide major contributions to crop diversification, the primary component of integrated crop and pest management. The only constraint for crop production in the less intensive tillage practice in the present study was the soil compaction. This can be addressed by subsoiling or other suitable soil-loosening methods prior to the conversion to conservation or no-tillage systems. The present study shows that soybean cultivation in the early transition period to conservation and no-tillage systems can be very productive when adequate crop and weed management measures are implemented.

Author Contributions: Conceptualization, R.L.; methodology, S.A. and R.L.; formal analysis, S.A.; investigation, S.A.; writing — original draft preparation, S.A.; writing-review and editing, S.A. and R.L.; funding acquisition, R.L. All authors have read and agreed to the published version of the manuscript.

Funding: This research was funded by the Slovenian Research Agency within the CRP (Slovenian abbreviation for target research program) V4-1815 and V4-2022 Rec-till. Core financing by the Slovenian Research Agency is acknowledged (P4-0133 grant and PhD scholarship of S.A.). This study was also supported by the European Union's Horizon 2020 research and innovation program under grant agreement No. 727321 (IWMPRAISE).

Data Availability Statement: The data presented in this study are available on request from the corresponding author.

Acknowledgments: The authors are grateful to Anže Rovanšek for his dedicated work and skillful technical solutions. We would also like to thank co-workers of the Agricultural Institute of Slovenia, at the Department of the Jablje Infrastructure Centre for optimally implemented agro-technical measures.

Conflicts of Interest: The authors declare no conflict of interest. The funders had no role in the design of the study, in the collection, analyses, or interpretation of data, in the writing of the manuscript, or in decision to publish the results.

\section{References}

1. Shahbandeh, M. Soybean Production Worldwide 2012/13-2019/20, by Country. Statista 2020. Available online: https://www. statista.com/statistics/263926/soybean-production-in-selected-countries-since-1980/ (accessed on 20 December 2020).

2. Elhady, A.; Hallmann, J.; Heuer, H. Symbiosis of soybean with nitrogen fixing bacteria affected by root lesion nematodes in a density-dependent manner. Sci. Rep. 2020, 10, 1619. [CrossRef] [PubMed]

3. Bertheau, Y.; Davison, J. Soybean in the European Union, status and perspective. In Recent Trends for Enhancing the Diversity and Quality of Soybean Products; Krezhova, D., Ed.; IntechOpen Access: London, UK, 2011; pp. 3-47. Available online: https:/ / www.intechopen.com/books/recent-trends-for-enhancing-the-diversity-and-quality-of-soybean-products / soybean-in-the-european-union-status-and-perspective (accessed on 1 February 2021).

4. Gawęda, D.; Nowak, A.; Haliniarz, M.; Woźniak, A. Yield and Economic Effectiveness of Soybean Grown Under Different Cropping Systems. Int. J. Plant Prod. 2020, 14, 475-485. [CrossRef] 
5. Hungria, M.; Campo, R.J.; Mendes, I.C. A Importância do Processo de Fixação Biológica de Nitrogênio para a Cultura da Soja: Componente Essencial para a Competitividade do Produto Brasileiro; Embrapa Soja: Londrina, Brazil, 2007; 80p.

6. Ferguson, B.J. The development and regulation of soybean nodules. In A Comprehensive Survey of International Soybean ResearchGenetics, Physiology, Agronomy, and Nitrogen Relationships; Board, J.E., Ed.; IntechOpen Access: London, UK, 2013 ; pp. 31-47.

7. Iannetta, P.P.M.; Young, M.; Bachinger, J.; Bergkvist, G.; Doltra, J.; Lopez-Bellido, R.J.; Monti, M.; Pappa, V.A.; Reckling, M.; Topp, C.; et al. A Comparative Nitrogen Balance and Productivity Analysis of Legume and Non-legume Supported Cropping Systems: The Potential Role of Biological Nitrogen Fixation. Front. Plant Sci. 2016, 7, 1700. [CrossRef]

8. Harper, J.E. Soil and Symbiotic Nitrogen Requirements for Optimum Soybean Production 1. Crop. Sci. 1974, 14, 255-260. [CrossRef]

9. Ohyama, T.; Tewari, K.; Ishikawa, S.; Tanaka, K.; Kamiyama, S.; Ono, Y.; Hatano, S.; Ohtake, N.; Sueyoshi, K.; Hasegawa, H.; et al. Role of Nitrogen on Growth and Seed Yield of Soybean and a New Fertilization Technique to Promote Nitrogen Fixation and Seed Yield. In Soybean-The Basis of Yield, Biomass and Productivity; IntechOpen Access: London, UK, 2017; pp. $153-185$.

10. Canfield, D.E.; Glazer, A.N.; Falkowski, P.G. The Evolution and Future of Earth's Nitrogen Cycle. Science 2010, 330, 192-196. [CrossRef] [PubMed]

11. Siczek, A.; Lipiec, J. Soybean nodulation and nitrogen fixation in response to soil compaction and surface straw mulching. Soil Tillage Res. 2011, 114, 50-56. [CrossRef]

12. Gentry, L.; Below, F.; David, M.; Bergerou, J. Source of the soybean N credit in maize production. Plant Soil 2001, 236, 175-184. [CrossRef]

13. Food and Agriculture Organization of the United Nations and Intergovernmental Technical Panel on Soils. Status of the World's Soil Resources (SWSR)_Main Report; Food and Agriculture Organization of the United Nations and Intergovernmental Technical Panel on Soils: Rome, Italy, 2015; 650p.

14. Schillinger, W.F. Minimum and Delayed Conservation Tillage for Wheat-Fallow Farming. Soil Sci. Soc. Am. J. 2001, 65, 1203-1209. [CrossRef]

15. Fernandez-Cornejo, J.; Hallahan, C.; Nehring, R.; Wechsler, S. Conservation tillage, herbicide use, and genetically engineered crops in the United States: The case of soybeans. AgBioForum 2012, 15, 231-241. Available online: https://agbioforum.org/wpcontent/uploads/2021/02/AgBioForum-15-3-231.pdf (accessed on 17 February 2021).

16. Givens, W.A.; Shaw, D.R.; Kruger, G.R.; Johnson, W.; Weller, S.C.; Young, B.G.; Wilson, R.G.; Owen, M.D.K.; Jordan, D. Survey of Tillage Trends Following the Adoption of Glyphosate-Resistant Crops. Weed Technol. 2009, 23, 150-155. [CrossRef]

17. Price, A.J.; Balkcom, K.S.; Culpepper, S.A.; Kelton, J.A.; Nichols, R.L.; Schomberg, H. Glyphosate-resistant Palmer amaranth: A threat to conservation tillage. J. Soil Water Conserv. 2011, 66, 265-275. [CrossRef]

18. Page, K.L.; Dang, Y.P.; Dalal, R.C. The Ability of Conservation Agriculture to Conserve Soil Organic Carbon and the Subsequent Impact on Soil Physical, Chemical, and Biological Properties and Yield. Front. Sustain. Food Syst. 2020, 4, 4. [CrossRef]

19. Sánchez, E.J.G.; Ordóñez-Fernández, R.; Carbonell-Bojollo, R.; Veroz-González, O.; Gil-Ribes, J.A. Meta-analysis on atmospheric carbon capture in Spain through the use of conservation agriculture. Soil Tillage Res. 2012, 122, 52-60. [CrossRef]

20. Brouder, S.; Gomez-Macpherson, H. The impact of conservation agriculture on smallholder agricultural yields: A scoping review of the evidence. Agric. Ecosyst. Environ. 2014, 187, 11-32. [CrossRef]

21. Kertész, Á.; Madarász, B. Conservation Agriculture in Europe. Int. Soil Water Conserv. Res. 2014, 2, 91-96. [CrossRef]

22. Fecák, P.; Šariková, D.; Černý, I. Influence of tillage system and starting N fertilization on seed yield and quality of soybean Glycine max (L.) Merrill. Plant Soil Environ. 2010, 56, 105-110. [CrossRef]

23. Temperly, R.J.; Borges, R. Tillage and Crop Rotation Impact on Soybean Grain Yield and Composition. Agron. J. 2006, 98, 999-1004. [CrossRef]

24. Kihara, J.; Bationo, A.; Waswa, B.; Kimetu, J.M.; Vanlauwe, B.; Okeyo, J.; Mukalama, J.; Martius, C. Effect of reduced tillage and mineral fertilizer application on maize and soybean productivity. Exp. Agric. 2012, 48, 159-175. [CrossRef]

25. Singer, J.W.; Logsdon, S.D.; Meek, D.W. Soybean Growth and Seed Yield Response to Tillage and Compost. Agron. J. 2008, 100, 1039-1046. [CrossRef]

26. Ferreira, M.C.; Andrade, D.D.S.; Chueire, L.M.D.O.; Takemura, S.M.; Hungria, M. Tillage method and crop rotation effects on the population sizes and diversity of bradyrhizobia nodulating soybean. Soil Biol. Biochem. 2000, 32, 627-637. [CrossRef]

27. Hardarson, G.; Danso, S.K.A. Methods for measuring biological nitrogen fixation in grain legumes. Plant Soil 1993, 152, 19-23. [CrossRef]

28. Tajima, R.; Lee, O.N.; Abe, J.; Lux, A.; Morita, S. Nitrogen-Fixing Activity of Root Nodules in Relation to Their Size in Peanut (Arachis hypogaea L.). Plant Prod. Sci. 2007, 10, 423-429. [CrossRef]

29. Ayanaba, A.; Nangju, D. Nodulation and nitrogen fixation in six grain legumes. In Proceedings of the First IITA Grain Legume Improvement Workshop, International Institute of Tropical Agriculture, Ibadan, Nigeria, 29 October-2 November 1973; pp. 198-204.

30. Kombiok, J.M.; Buah, S.S.J. Tillage depth effects on nodulation, nitrogen fixation and yield of three soybean varieties in the Northern Savanna zone of Ghana. Afr. J. Agric. Res. 2013, 8, 2340-2345. [CrossRef]

31. Kemal, D.; Ismail, C.; Mustafa, G.; Ali, C.; Dogan, K.; Celik, I.; Gok, M.; Coskan, A. Effect of different soil tillage methods on rhizobial nodulation, biyomas and nitrogen content of second crop soybean. Afr. J. Microbiol. Res. 2011, 5, 3186-3194. [CrossRef] 
32. Kihara, J.; Martius, C.; Bationo, A.; Vlek, P.L.G. Effects of Tillage and Crop Residue Application on Soybean Nitrogen Fixation in a Tropical Ferralsol. Agriculture 2011, 1, 22-37. [CrossRef]

33. Santner, J.; Mannel, M.; Burrell, L.D.; Hoefer, C.; Kreuzeder, A.; Wenzel, W.W. Phosphorus uptake by Zea mays L. is quantitatively predicted by infinite sink extraction of soil P. Plant Soil 2015, 386, 371-383. [CrossRef]

34. Food and Agriculture Organization of the United Nations. Standard opening procedure for soil organic carbon. In Walkley-Black Method: Titration and Colometric Method; FAO: Rome, Italy, 2019; 27p. Available online: http:/ /www.fao.org/3/ca7471en/ca747 1en.pdf (accessed on 4 October 2021).

35. Sáez-Plaza, P.; Navas, M.J.; Wybraniec, S.; Michałowski, T.; Asuero, A.G. An Overview of the Kjeldahl Method of Nitrogen Determination. Part II. Sample Preparation, Working Scale, Instrumental Finish, and Quality Control. Crit. Rev. Anal. Chem. 2013, 43, 224-272. [CrossRef]

36. Munger, P.; Bleiholder, H.; Hack, H.; Hess, M.; Stauss, R.; Van den Boom, T.; Weber, E. Phenological Growth Stages of the Soybean Plant (Glycine max (L.) Merr.)—Codification and Description according to the General BBCH Scale-With Figures. J. Agron. Crop Sci. 1997, 179, 209-217. [CrossRef]

37. Filho, E.A.M.; Da Silva, A.P.; Figueiredo, G.C.; Gimenes, F.H.S.; Vitti, A.C. Compared performance of penetrometers and effect of soil water content on penetration resistance measurements. Revista Brasileira de Ciência do Solo 2014, 38, 744-754. [CrossRef]

38. R Core Team. R: A Language and Environment for Statistical Computing; R Core Team: Vienna, Austria, 2019.

39. Dick, W.A.; Van Doren, D.M. Continuous Tillage and Rotation Combinations Effects on Corn, Soybean, and Oat Yields 1. Agron. J. 1985, 77, 459-465. [CrossRef]

40. Meese, B.; Carter, P.; Oplinger, E.; Pendleton, J. Corn/Soybean Rotation Effect as Influenced by Tillage, Nitrogen, and Hybrid/Cultivar. J. Prod. Agric. 1991, 4, 74-80. [CrossRef]

41. Jug, D.; Sabo, M.; Jug, I.; Stipesevic, B.; Stosic, M. Effect of different tillage systems on the yield and yield components of soybean [Glycine max (L.) Merr.]. Acta Agron. Hung. 2010, 58, 65-72. [CrossRef]

42. Lasisi, D. Effects of Tillage Methods on Soybean Growth and Soil Properties. Ph.D. Thesis, Department of Agricultural Engineering, Obafemi Awolowo University, Ile-Ife, Nigeria, 2008.

43. Lasisi, D.; Aluko, O.B. Effects of tillage methods on soybean growth and yield in a tropical sandy loam soil. Int. Agrophys. 2009, 23, 147-153.

44. Matsuo, N.; Tsuchiya, S.; Nakano, K.; Fukami, K. Design and evaluation of a one-operation shallow up-cut tillage sowing method for soybean production. Plant Prod. Sci. 2019, 22, 465-478. [CrossRef]

45. Sidiras, N.; Henklain, J.C.; Derpsch, R. Comparison of three different tillage systems with respect to aggregate stability, the soil and water conservation and the yields of soybean and wheat on an oxisol. In Proceedings of the 9th Conference of the International Soil Tillage Research Organization, ISTRO, Osijek, Yugoslavia, June 1982; pp. 537-544.

46. Rodrígues, J.L.; Gamero, C.; Fernándes, J.C.; Mirás-Avalos, J. Effects of different soil tillage systems and coverages on soybean crop in the Botucatu Region in Brazil. Span. J. Agric. Res. 2009, 7, 173. [CrossRef]

47. Ozturk, F.; Sogut, T. The effect of tillage and plant density on yield and yield components of soybean [Glycine max (L.) Merrill] grown under main and double-cropping soybean. Int. Scientif. J. Mech. Agric. 2016, 62, 19-23.

48. Panasiewicz, K.; Faligowska, A.; Szymańska, G.; Szukała, J.; Ratajczak, K.; Sulewska, H. The Effect of Various Tillage Systems on Productivity of Narrow-Leaved Lupin-Winter Wheat-Winter Triticale-Winter Barley Rotation. Agronomy 2020, 10, 304. [CrossRef]

49. Pedersen, P.; Lauer, J.G. Corn and Soybean Response to Rotation Sequence, Row Spacing, and Tillage System. Agron. J. 2003, 95, 965-971. [CrossRef]

50. Cober, E.R.; Morrison, M.J.; Ma, B.; Butler, G. Genetic Improvement Rates of Short-Season Soybean Increase with Plant Population. Crop. Sci. 2005, 45, 1029-1034. [CrossRef]

51. Neugschwandtner, R.W.; Winkler, J.; Bernhart, M.; Pucher, M.A.; Klug, M.; Werni, C.; Adam, E.; Kaul, H.-P. Effect of row spacing, seeding rate and nitrogen fertilization on yield and yield components of soybean. Die Bodenkultur J. Land Manag. Food Environ. 2019, 70, 221-236. [CrossRef]

52. Yilmaz, N. The Effects of Seed Rate on Yield and Yield Components of Soybean (Glycina max L. Merill). Pak. J. Biol. Sci. 2003, 6, 373-376. [CrossRef]

53. Stock, H.G.; Warnstorff, K.; Kazmi, M. Analyse der Ertragsstruktur von Sojabohnen (Glycine max [L.] Merr.) auf einem Standort im mitteldeutschen Trockengebiet. Austr. J. Agric. Res. 1996, 47, $23-32$.

54. Thiagalingam, K.; Gould, N.; Watson, P. Effect of tillage on rainfed maize and soybean yield and the nitrogen fertilizer requirements for maize. Soil Tillage Res. 1991, 19, 47-54. [CrossRef]

55. Matowo, P.R.; Pierzynski, G.M.; Whitney, D.A.; Lamond, R.E. Long Term Effects of Tillage and Nitrogen Source, Rate, and Placement on Grain Sorghum Production. J. Prod. Agric. 1997, 10, 141-146. [CrossRef]

56. Hanhur, V.; Marenych, M.; Yeremko, L.; Yurchenko, S.; Hordieieva, O.; Korotkova, I. The effect of soil tillage on symbiotic activity of soybean crops. Bulg. J. Agric. Sci. 2020, 26, 365-374.

57. King, C.A.; Purcell, L.C. Soybean Nodule Size and Relationship to Nitrogen Fixation Response to Water Deficit. Crop. Sci. 2001, 41, 1099-1107. [CrossRef]

58. De Campos, B.-H.C.; Gnatta, V. Inoculantes e fertilizantes foliares na soja em área de populações estabelecidas de Bradyrhizobium sob sistema plantio direto. Revista Brasileira de Ciência do Solo 2006, 30, 69-76. [CrossRef] 
59. Hungria, M.; Mendes, I.C. Nitrogen Fixation with Soybean: The Perfect Symbiosis? In Biological Nitrogen Fixation; Wiley: Hoboken, NJ, USA, 2015; pp. 1009-1024.

60. Franzluebbers, A. Soil organic matter stratification ratio as an indicator of soil quality. Soil Tillage Res. 2002, 66, 95-106. [CrossRef]

61. van Kessel, C.; Hartley, C. Agricultural management of grain legumes: Has it led to an increase in nitrogen fixation? Field Crop. Res. 2000, 65, 165-181. [CrossRef]

62. Green, C.J.; Blackmer, A.M. Residue Decomposition Effects on Nitrogen Availability to Corn following Corn or Soybean. Soil Sci. Soc. Am. J. 1995, 59, 1065-1070. [CrossRef]

63. Norman, R.J.; Gilmour, J.T.; Wells, B.R. Mineralization of Nitrogen from Nitrogen-15 Labeled Crop Residues and Utilization by Rice. Soil Sci. Soc. Am. J. 1990, 54, 1351-1356. [CrossRef]

64. Waldroup, P.W. Whole Soybeans for Poultry Feeds. World's Poult. Sci. J. 1982, 38, 28-35. [CrossRef]

65. Szwejkowska, B. Effect of cultivation intensity on protein content and yields in field pea. Acta Sci. Pol. Agric. 2005, 4, 153-161.

66. Redondo-Cuenca, A.; Suárez, M.J.V.; Mateos-Aparicio, I. Soybean seeds and its by-product okara as sources of dietary fibre. Measurement by AOAC and Englyst methods. Food Chem. 2008, 108, 1099-1105. [CrossRef] [PubMed]

67. Chetan, C.; Rusu, T.; Simon, A. Research regarding the influence weed control treatments on production and qualitative indicators soybean cultivated in minimum tillage system. Bull. Univ. Agric. Sci. Vet.-Med. Cluj-Napoca Agric. 2016, 73, 170-175. [CrossRef]

68. Soane, B.D.; Owerkerk, C. Soil Compaction in Crop Production; Elsevier: Amsterdam, The Netherlands, 1994; 662p.

69. Mosaddeghi, M.R.; Hajabbasi, M.; Hemmat, A.; Afyuni, M. Soil compactibility as affected by soil moisture content and farmyard manure in central Iran. Soil Tillage Res. 2000, 55, 87-97. [CrossRef]

70. Khan, F.U.H.; Tahir, A.R.; Yule, I.J. Intrinsic implication of different tillage practices on soil penetration resistance and crop growth. Int. J. Agric. Biol. 2001, 3, 23-26. 